\title{
Not Yet: The Faith of Revolution
}

Cory Stockwell

Toward the end of his 1993 text Sauf le nom, Derrida employs the word 'revolution' on two occasions. This might strike us as strange in a text that is ostensibly a reading of the seventeenth-century poet and mystic Angelus Silesius, and which, more broadly, deals with the relationship between deconstruction and negative theology. The word comes up in the midst of a discussion of Silesius's treatment of God in his Cherubinic Wanderer: the nature of God, what is proper to him, what he keeps secret and what he gives forth; more specifically, how he gives forth that which he does not possess and hence cannot give.

The passage in question bears on the theme of contamination. After wondering whether Silesius is the best example to employ in a discussion of negative theology, Derrida notes that, in a way, there is no text that fits fully within this tradition, for the simple reason that it is everywhere. 'I don't believe,' writes Derrida, 'that any text is not in some way contaminated by negative theology, even among those texts that apparently do not have, want, or believe they have any relation with theology in general." What is it that gives negative theology this power of contamination, this ability to turn up - to speak - in places where it is least expected? This question runs counter to the ways we usually think of negative theology, whose modus operandi seems to set up to avoid a particular contamination, that of language: when I seek to approach God, reasons the negative theologian, I run the risk of perverting or contaminating his nature in my words, since by attributing qualities or characteristics to him, I do an injustice to his essential unknowability; and hence the best way to do justice to God is to say what he is not, and to register, via this negation, his

The Oxford Literary Review 36.1 (2014): 115-135

DOI: 10.3366/olr.2014.0090

(C) Edinburgh University Press

www.euppublishing.com/olr 
very inaccessibility. I must literally speak what he is not - speak his nothingness, in a sense - and for this reason, negative theology, as Derrida notes on two occasions, has often been accused of being an atheism. $^{2}$

In any case, this is how negative theology seeks, as Derrida puts it, 'to say and join what is proper to God' (69/82, translation modified, Derrida's emphasis). But what is the proper if 'the proper of this proper consists in expropriating itself, if the proper of the proper is precisely, justly, to have nothing of its own?' (69/82, Derrida's emphasis). Derrida is strikingly close to Silesius here, whom he cites:

What is God's own proper? to pour forth in creation

To be the same in all times, to have, want, know nothing. (Quoted in Derrida, 70/83)

A seeming contradiction: God pours forth, yet has nothing. And Derrida immediately refers to this giving without having (which he compares to the working of the Good in Plotinus, and in which the resonances of the concept of kenosis are clear) with the term revolution.

Now this revolution, at once interior and exterior, which makes philosophy, onto-theological metaphysics, pass over the other edge of itself, is also the condition of its translatability. What makes philosophy go outside itself calls for a community that overflows its tongue and undertakes a process of universalization.

- What makes it go outside itself would come to it thus already from the outside, from the absolute outside. That is why the revolution could not be only internal.

- That's exactly what it says, what the mystics and the theologians of apophasis say when they speak of an absolute transcendence that announces itself from within. All that comes down to the same or, indifferently, to the other. (70/84, translation modified)

What exactly does this twice-named (or thrice-named, if we include the 'it' of the first sentence of the final 'utterance') revolution indicateor rather, why does Derrida name this giving of that which one does not have, this going outside oneself or itself, a revolution? We get an 
indication from both the second and third utterances above, where Derrida seems to indicate a back and forth movement from inside to outside and vice versa - wouldn't revolution, according to the logic of the term, name a movement by which an entity goes away, only to come back... to itself? Yet this is not exactly what Derrida indicates: he mentions Silesius's pouring forth of the non-proper, this impossible gift, yet he never gestures toward any counter-movement, even if that which pours forth somehow comes from without. What is clear, in other words, is that this pouring-forth is not balanced by a replenishing: somehow, nothing gives forth, and continues to do so. How are we to understand this, and why exactly is it a revolution?

Whatever the answer may be, let us make two observations at this point. First, Derrida clearly indicates a relationship between this revolution and speaking. Saufle nom, after all, is a book that is obsessed by speech, from the fact that it is set up as a conversation between two interlocutors, ${ }^{3}$ to its constant references to speaking in all of its variations. We need merely glance at the end of the passage cited above to see this at work: revolution, Derrida writes, says a transcendence that announces itself from within. What we are dealing with, in other words, is a kind of revolutionary voice, one that speaks at the intersections of negative theology and deconstruction.

And this is the second observation: that Derrida, throughout this text, is concerned with the links, intersections, blurring of boundaries, between negative theology and deconstruction. To say this is to veer into controversial territory, given that, since his first writings, Derrida has been 'accused'4 of being a negative theologian, or at least of employing the methods of this tradition. The debate around these issues still rages, and the most prominent recent writer to take part in it is Martin Hägglund. In his 2008 book Radical Atheism: Derrida and the Time of Life, Hägglund argues that it is misguided to speak of any link between Derrida and negative theology, since the latter 'adheres to the most traditional metaphysical logic by positing an instance that is exempt from temporal finitude'. It is important to note that Hägglund, in making this claim, draws on the words of Derrida himself, who in 1968 wrote of différance that it is

not theological, not even in the order of the most negative of all negative theologies, which are always concerned with disengaging a 
superessentiality beyond the finite categories of essence and existence, that is, of presence, and always hastening to recall that God is refused the predicate of existence, only in order to acknowledge his superior, inconceivable, and ineffable mode of being. Such a development is not in question here. ${ }^{6}$

Hägglund quotes most of this passage early in his book, and with reason: the testimony of Derrida on this matter, in what is perhaps his most famous essay, is obviously very important. But even more interesting from our standpoint are the words Hägglund writes immediately after this quotation: 'Derrida repeats the same argument in his two main texts on negative theology: "How to Avoid Speaking" and Saufle nom' (4).

This is an extremely strange claim. Why would Derrida write two entire texts - a book and a long essay - in order to repeat an argument made years before? ${ }^{7}$ A cursory glance at either of these texts shows that this is simply not the case: early in Saufle nom, for example, we read that Silesius's thought 'seems strangely familiar to the experience of what is called "deconstruction" (43/31, translation modified); a bit further on: 'All the apophatic mystics can also be read as powerful discourses on death, on the (impossible) possibility of the proper death of the being-there that speaks' (44/34); later in this passage, Derrida writes that the 'coherence' between negative theology and the thought of Heidegger 'seems to me profound and the continuity rigorous' (45/34-5); and a few pages on, Derrida speaks of a series of traditional oppositions (form and content, concept and metaphor, etc.) that one 'can or must deconstruct,' but which negative theology has already 'powerfully contributed to calling into question' (49/45). Far from simply dismissing negative theology, as Hägglund would have us think, Derrida views the relationship between it and deconstruction as extremely complex: the two have much in common, and something interesting and indeed vital for Saufle nom takes place at their intersection, or in what we might think of as their mutual contamination.

The reasons for which Hägglund prevents himself from engaging with this relationship lie in his theoretical framework, which is heavily dependent on a certain concept: that of desire. This concept is at the 
heart of what he calls radical atheism, as he explains at the beginning of the book:

Atheism has traditionally limited itself to denying the existence of God and immortality, without questioning the desire for God and immortality. Thus, in traditional atheism mortal being is still conceived as a lack of being that we desire to transcend. In contrast, by developing the logic of radical atheism, I argue that the so-called desire for immortality dissimulates a desire for survival that precedes it and contradicts it from within. (1)

Traditional atheism, Hägglund argues, has not gone far enough: it has denied the existence of God, but this denial has usually taken the form of a lament. The task of radical atheism, on the contrary, is to affirm mortal being, indeed to desire what Hägglund calls the 'time of life,' in which every moment is a matter of survival. Indeed, this is not a matter of choice, since the religious notion of immortality contradicts itself: the existence of an immortal realm, unscathed or uncontaminated by time, would make life impossible, since life is predicated on the idea that it may come to an end at any moment, and if this were not the case, one would never have the desire to do anything. ${ }^{8}$ The very fact of living is thus an affirmation of finitude, and renders impossible the notion of an immortality unscathed or uncontaminated by time.

Hägglund's claims are clearly compelling, as is evidenced by the far-reaching debates that his book has provoked. Indeed, to my mind, his work is not only interesting but urgent, not only from a theoretical but also from a political standpoint, given the extent to which 'religious' claims - or, to be more specific, claims based on the assumption of 'indemnity', a realm uncontaminated by timehave come to be viewed as acceptable in contemporary political discourse. Yet there is something about this book - which claims to work within deconstruction, and which takes up and expands many of Derrida's arguments - that is very strange for any serious reader of Derrida, and that is just how 'non-Derridean' the book often seems.' One can take as an index of this Hägglund's reliance on clear, discrete oppositions. Writing about the relationship - or, in his view, non-relationship - between deconstruction and religion, 
for example, Hägglund writes: 'all attempts to assimilate Derrida's thinking to a religious framework are wrongheaded' (116); ${ }^{10}$ more specifically, concerning negative theology, he argues that 'the logic of negative theology and the logic of deconstruction are diametrically opposite' (5). Indeed, the book abounds in claims about traditions that are the 'diametrical opposite' of deconstruction, and about thinkers who 'completely misunderstand' or 'systematically misread' Derrida, as though what were at stake was the protection of his work from their contamination. ${ }^{11}$

Hägglund is of course free to make his arguments in any way he sees fit, and he himself notes the distinction between his work and that of Derrida, and at the same time makes an important point about reading the latter, when he writes in the introduction that his aim is 'not simply to accept what is handed down' from Derrida, but 'to reaffirm [his] legacy in order to make it live on in a different way' (12). I sympathize with what Hägglund says here-uncritical acceptance, after all, has no place in analysis. But what exactly are the stakes of Hägglund's very different approach? Does this approach, in a book that claims time and again to work within 'deconstructive logic', ${ }^{12}$ mean that Hägglund misses something essential about Derrida's thinking specifically, where the interests of this essay are concerned, Derrida's thinking about negative theology, and more broadly, the place of faith in deconstruction?

In order to respond to these questions, we turn first to the poet Derrida reads in Saufle nom, Angelus Silesius.

And specifically, to the theme of nothingness in Silesius. Hägglund is deeply critical of the ways negative theology conceives of nothingness, writing the following: 'There is nothing radical about saying that God is nothing as long as one means that God is nothing that can be apprehended by a finite being, but is infinitely superior to anything that can be described in language' (4). ${ }^{13}$ But is this the last word on nothingness in negative theology? We will respond to this question by thinking about the prominent place this theme occupies in Silesius - indeed, the experience of nothingness is crucial throughout the Cherubinic Wanderer. Silesius writes, for instance, that in order to approach God, 'You must be nothing / want nothing';14 a little later, he writes that 'God is truly nothing' (I: 200). Some verses seem entirely 
devoted to the theme of nothingness, for example this one, which Derrida quotes:

\section{To become Nothing is to become God}

Nothing becomes what it is before: if you do not become nothing, Never will you be born of eternal light. (VI: 130) ${ }^{15}$

Or this one:

Wanting nothing makes one like God.

God is eternal peace / because he searches for and wants nothing: If you also want nothing / you are even more. (I: 76)

This last verse is especially interesting for our purposes, since it deals with desire, and read from a certain standpoint, it could be seen to provide evidence for Hägglund's claims about negative theology: Silesius writes, after all, that in wanting nothing, one becomes 'more.' In this sense, the verse appears to fit neatly within the logic of the concept most often associated with negative theology: that of apophasis. Apophasis, as we usually understand it, describes a negation by way of which one approaches God: I make a statement about God, but since this statement attributes qualities to God - thus doing an injustice to his unknowability - I must immediately negate it; no sooner do I do this than my negation becomes an affirmation - an attribution of qualities to God — and the whole operation must begin again. In his 1994 book Mystical Languages of Unsaying, however, Michael A. Sells argues that the term 'negation' is not really a suitable translation for apophasis. 'Apophasis,' he writes, 'can mean "negation," but its etymology suggests a meaning that more precisely characterises the discourse in question: apo phasis (un-saying or speaking-away). ${ }^{, 16}$ This begs the question: what exactly is unsaid? Sells continues:

The term apophasis is commonly paired with kataphasis (affirmation, saying, speaking-with). Every act of unsaying demands or presupposes a previous saying. Apophasis can reach a point of intensity such that no single proposition concerning the transcendent can stand on its own. Any saying (even a negative saying) demands a correcting proposition, an unsaying. But that 
correcting proposition which unsays the previous proposition is in itself a 'saying' that must be 'unsaid' in turn. It is in the tension between the two propositions that the discourse becomes meaningful. That tension is momentary. It must be continually reearned by ever new linguistic acts of unsaying. (2-3)

Unsaying, within this understanding, works in a back and forth movement with saying or affirmation, and meaning is produced in the tension between these poles. We can immediately see this logic in Silesius: in the last verse we cited, for example, one approaches God by wanting nothing; through wanting nothing, however, one becomes 'more' ('vil'), and this re-affirmation necessitates another act of unsaying in order to undo it. Going away, language comes back, in a kind of revolutionary movement.

But does this really get to the heart of what is happening in Silesius? Let us consider his claim 'One finds God by not-searching (mit nicht-suchen)' (I: 171). To say this is not simply to negate the affirmation 'one finds God through searching': it is rather to say that one approaches God in an experience of undoing or (to follow Sells) unsaying one's own search for him, an experience of letting go of or abandoning the search that does not mean ceasing to search, but rather that the search (or the 'not-search') takes place in its abandonment: search and abandonment, in this schema, are somehow one and the same. ${ }^{17}$ Rather than adding (to one's knowledge, devoutness, etc.) in order to approach God, one must instead take away: the more one subtracts, the closer one gets to God, as though God, far from a presence arrived at by way of an absence, were simply an absence.

This doesn't really perturb Hägglund's claims, however: even if Silesius's God were pure nothingness, this nothingness could still be said to lie 'somewhere else', in a beyond, a transcendent realm, and in unsaying God, one would still be positing a superior being (even if in the form of a nothingness). But Silesius puts forth yet another understanding. Let us think about another statement he makes about looking for, or in this case finding, God: 'God is found in weakness' (I: 57). What is weakness? It is certainly not a zero-point or absence of strength; rather, it is usually thought of as something less than strength, a reduction or diminution of the latter. But can we think of weakness in 
terms other than purely negative ones? If strength is usually associated with a fullness of presence, a wholeness or a completion, then we can think of weakness not as a lack, but as a work of incompletion; ${ }^{18}$ God, in Silesius's formulation, would thus be found at that moment at which one undertakes this work of incompletion on oneself. Silesius's term for this is 'capable incapacity' or 'capable weakness,' to suggest an awkward translation of the title of one of his verses, 'Das Vermoegende Unvermoegen.' The verse runs thus:

He who desires nothing / has nothing / knows nothing / loves nothing / wants nothing;

Has / knows / desires / and loves all the more. (I: 45)

Clearly, there is an affirmation that occurs by way of a negation in this verse, and we seem once more to be within the play of apophasis and kataphasis. But let's think about precisely how this happens. In one respect, the more ('jmmer vil') undoes all of the work of the nothing from the first line: we move from a lessening or a move toward nothing to a 'more.' Yet this isn't a back and forth movement: one doesn't switch from having and wanting nothing in the first line, to obtaining 'something' in the second; rather, the 'more' indicates the ever-decreasing move toward nothingness: the capacity of this incapacity lies not in an increase that would follow a decrease, but rather in an ability to continually lessen, to ceaselessly incomplete.

I have mentioned that my translation of this verse's title is awkward, which raises the question of how it has been translated elsewhere. Roger Munier's French translation is instructive: 'La riche pauvreté.' ${ }^{\prime 9}$ The choice of this final word is interesting for our purposes. Silesius himself uses it often, for example in this verse in which poverty comes up three times:

Poverty is divine.

God is the poorest thing / He is pure and free:

That's why I say rightly and truly / that poverty is divine. (I: 65)

In one sense, there is nothing new about ascribing a divinity to poverty, given the latter's importance in Christianity, not to mention at very 
least the other monotheisms. But this is a unique formulation of poverty. Let's begin with the term 'the poorest thing' - what exactly does this mean? That God, of all the 'things' that exist, is somehow 'the poorest,' and we should think about how radical a conception this is: regardless of how small or poor something might appear, God is even poorer; he is in other words, and contrary to the ostensible grammar of the formulation, outside of comparison, for he is poorer than any thing that can be thought, and thus cannot be one thing among many. Indeed, the formulation 'the poorest' resonates with the well-known conception of God as the 'Most High', whereby God is always beyond any entity that can be thought. In Silesius's formulation, God, rather than the 'Most High', would consist of something like the 'most low' or 'most small' - or rather, 'most poor'. This would appear to repeat the logic of the Most High, whereby God is 'elsewhere', beyond or transcendent. But in another verse, Silesius indicates that we should understand this poverty differently.

\section{To the sinner}

The richest devil has not even a pebble:

You are a slave of the most poor: can you be even poorer? (Du bist des aermbsten Sclav: kan auch was aermers seyn?) (III: 96, Silesius's emphasis)

God is thus 'the most poor, ${ }^{20}$ again seemingly inhabiting a transcendent realm. But let's think about exactly how Silesius formulates this. Immediately after informing 'the sinner' that he is a slave of the most poor, he asks: 'can you be even poorer?' 'The most poor' or 'the poorest,' in other words, is not something unattainable: it is that aspect of poverty that ceaselessly 'surpasses' itself, that which is always becoming poorer ... than itself. Far from a beyond, it would be more accurate to say that it is the experience of a 'before': it is that which just precedes the experience of fullness, that which makes fullness ever so slightly less than itself. This, quite simply, is the experience to which Silesius gives the name 'God' (to which only this name could apply): the experience by way of which, at every moment, one incompletes oneself; the experience by way of which, at every moment, one becomes even poorer than one was before. 
And this is the moment to return to one of the first verses of Silesius that we looked at, a verse concerning desire. Recall that Silesius writes: 'Nichts wollen macht GOtte gleich' (I: 76); God searches for and desires nothing, and if you do the same, you are even more. But our understanding of the work of impoverishment in Silesius allows us to read this verse differently. What Silesius suggests is not that, by way of desiring nothing, one approaches the fullness or the transcendence of God. His affirmation is altogether different: the divine, in this formulation, is located not so much in or beyond the desire for nothing, as in the rendering-nothing, the annihilation, of one's own desire. To want nothingness, in other words, is not to desire a beyond: it is rather to impoverish one's own desire, to hollow it out, to ceaselessly render it less than it was before. To unsay desire, without the fullness of a saying ever coming to take its place, ever coming to redeem it.

A desire unsaid, unspoken, or better, that speaks its own poverty, that speaks in a voice with no lungs behind it, we might say, paraphrasing Kafka. $^{21}$ Is it any surprise that the two greatest twentieth century thinkers of neutrality, Blanchot and Barthes, were both drawn to Silesius? ?2 $^{22}$ The neutral, after all, designates a work of lessening, the hollowing out of a fullness, that which 'ruins everything, all the while leaving everything intact. ${ }^{, 23}$ And indeed, Derrida is not far from these formulations of the neutral when he speaks about desire in Sauf le nom: when he suggests, for example, that there are two types of apophasis, one that can 'respond to, correspond to, correspond with the most insatiable desire of God', while at the same time ' $[t]$ he other apophasis, the other voice, can remain radically foreign to all desire, in any case to every anthropo-theomorphic form of desire' (37/18-19, Derrida's emphasis, translation modified); or when, in response to this formulation, he asks: 'But isn't it proper to desire to carry within it its own suspension, the death or the phantom of desire? To go toward the absolute other, isn't that the extreme tension of a desire that tries thereby to renounce its own force, its own movement of appropriation?' (37/19, translation modified). When we speak of apophasis, Derrida says with the very last words of the book, we are speaking of a 'literature' that 'holds desire in suspense (tient le désir en haleine), and always saying too much or too little, it leaves you at each 
moment without ever departing' (85/113-114, translation modified). What is this renounced, suspended, ghostly desire; what is this voice of desire that speaks with bated breath?

Let us note at this point just how close we are to negative theology, and indeed to an experience of faith that negative theology articulates. I am thinking specifically of the theme of Gelassenheit (a term we usually associate with Meister Eckhart, but which is also very important for Silesius $\left.^{24}\right)$, and indeed, are not Derrida's final words - 'elle vous laisse chaque fois sans vous quitter jamais' (114) — a perfect formulation of the thinking of faith that Gelassenheit undertakes? One could nonetheless argue that faith is what definitively separates Derrida from Silesius, as the latter's faith is of course deeply Christian. But one of the key arguments in Sauf le nom is that faith, in Silesius and in negative theology as a whole, cannot be reduced to its Christian element. Derrida writes the following of apophasis: 'An immediate but intuitionless mysticism, a sort of abstract kenosis, frees it from all authority, all narrative, all dogma, all belief — and at the limit, from all determinable faith' (71/86, Derrida's emphasis, translation modified ${ }^{25}$ ); we are dealing here with a mysticism that remains 'independent of all history of Christianity, absolutely independent' (71/86, Derrida's emphasis). This independent and indeterminable faith is nonetheless decidedly political: immediately after noting the independence of negative theology, Derrida writes: 'Whence the courage and the dissidence, potential or actual, of these masters (think of Eckhart), whence the persecution they suffered at times, whence their passion, whence this scent of heresy, these trials, this subversive marginality of the apophatic current in the history of theology and of the Church' (71/86); and these reflections come about shortly after Derrida has reflected upon apophasis's revolutionary nature. What is the political faith, indeed the revolutionary faith, that we are dealing with here?

Perhaps this word - faith - tells us everything we need to know. Perhaps what we are dealing with is a certain thinking of the future, one indicated by faith, a faith that names the suspended, impoverished desire of which we have just spoken. A faith, a future, that is in some way the deconstruction of desire. In order to think about this, we will pass again through Hägglund's book.

I argued above that the key concept in Hägglund's book is that of desire, and recall that this is always a desire for a radical atheism: as 
opposed to traditional atheism, which at times figures as a lament for the absence of God - a desire for an impossible presence - radical atheism is an affirmation of the 'time of life'. What is the nature of this time? In order to understand the way Hägglund conceives of it, we turn to the first chapter of his book, 'Autoimmunity of Time: Derrida and Kant'. Early in this chapter, Hägglund notes that Kant's treatment of time is based on the principle of noncontradiction: the present cannot contradict the future; they must remain discrete so as not to contaminate one another. How, then, is temporal synthesis possible? As Hägglund writes, 'Kant's solution to the problem is to contrast the ever-changing empirical consciousness with the unity of transcendental apperception' (23), in other words to locate a basis for the subject that is immune from the effects of time. Derrida's understanding of time is of course quite different:

Derrida argues that the unconditional is the spacing of time that divides every instance in advance and makes it essentially dependent on what is other than itself. What makes $\mathrm{X}$ possible is at the same time what makes it impossible for $\mathrm{X}$ to be in itself. Such is the minimal formula for the illogical logic of identity that deconstructive reason employs. (25, Hägglund's emphases)

Deconstruction thus challenges the principle of noncontradiction on which Kant's thought depends, all the while remaining 'logical', and the workings of this logic depend on what Hägglund refers to throughout this chapter as 'the structure of the trace': the present is always divided from itself; it is always at once the past that it has left behind (yet retains within itself), and the future that it anticipates (but which already works it over, transgresses it). This is what makes 'every instance,' as Hägglund says in the passage quoted above, 'other than itself.

Where the future is concerned, therefore, to live the 'time of life' means to be open to what is at once the chance and the threat of the future, and most importantly to embrace this alterity of the future - to say yes to it, to desire it. One cannot but agree on this point - what would the 'time of life' be if we could predict the future? - and indeed Hägglund insists again and again on this essential alterity or unknowability of the future: the phrases he uses most often 
to designate this are 'undecidable future' and 'undecidable coming of time'. 'The coming of the future', he writes, 'is strictly speaking "undecidable", since it is a relentless displacement that unsettles any definitive assurance or given meaning. One can never know what will have happened. Promises may always be turned into threats, friendships into enmities, fidelities into betrayals, and so on' (40, Hägglund's emphasis). Hence the agony of the decision in Derrida: 'it is because the future cannot be decided in advance that one has to make decisions' (40, Hägglund's emphasis).

In a way, this conception is very faithful to Derrida: who has taught us more about the unforeseeability and undecidability of the future, and more broadly, the intricate play of time and alterity, than he? What is it in these claims, then, that strikes us as so different from 'deconstructive logic', as Hägglund puts it? I am speaking of a tendency in Hägglund that moves him away from one of Derrida's most important insights, where time is concerned - ironically, that moves away from an aspect of the future that is tied intimately to the question of noncontradiction. We might think of this as the dual nature of the future. We will enter into this discussion by asking this question: is the future, for Hägglund, separate from the present? On the one hand, we have already seen that the answer is clearly no: Hägglund is careful to note that what he is dealing with is the synthesis of time onto which the structure of the trace opens. This renders all talk of distinctions complex. One of the ways he discusses this synthesis is via a discussion of Derrida's use of

the French verb arriver, which can mean to come, to happen, and to arrive. Derrida plays on these multiple meanings in order to reinforce that what happens cannot be given in the form of presence but is divided by the spacing of time. Every event is both superseded (no longer) and to come (not yet) in its very event. Whatever happens is therefore transgressed by the future and becomes past. (29, Hägglund's emphases)

This transgression of and by the future is deeply interesting: it shows that what is present can never only be present, but is rather divided within itself, spacing itself out into the future. Hägglund is nonetheless careful to note that this future, this to come, is not yet - he even 
emphasizes this term, which comes up again a couple of pages later, where he writes, in the context of a reading of Derrida's book Rogues, that

one cannot know in advance how one should act in relation to [the other]. On the contrary, the relation to the other is inseparable from the coming of time, which means that it may alter its character at every moment. One cannot face up to or even face the other (...) since the other is no longer or not yet. (31, Hägglund's emphases)

How exactly are we to read this recurring 'not yet'? On the one hand, nothing is more natural than to think of the future in this way: the future, after all, is that which has not yet happened. On the other hand, this 'not yet', which is consistent with Hägglund's concept of a time 'divided within itself, bearer of a constitutional separation from itself, reveals a tendency in Hägglund - one that coexists with the complex synthesis by which he understands time - to view the future as a beyond, as something that will arrive somewhere else. Strangely, in this book that seeks an openness to contamination, and in this chapter that aims to build an 'illogical logic' of noncontradiction, Hägglund insists on a division: a clear separation between present and future.

This is not to say that the future is not irreducibly other, unforeseeable, indeed 'not yet', and indeed on the very same page from which I have taken the last quotation, Hägglund cites a passage from Rogues in which Derrida argues that the logic of the event is marked by a 'passivity' or 'vulnerability' in which 'it is not yet or is already no longer possible to face or face up to the unforeseeability of the other' (quoted in Hägglund, 30-31). Yet Derrida's 'not yet' resonates in a way that is very different from that of Hägglund, and this difference is marked here by the word 'vulnerability' and, even better, 'passivity'. What does it mean to be passive with regards to the future? It means that, in some way, the future has already come - already come to pass, we might say - in its very status as not yet: the future is that element, at once irreducibly other, undecidable, etc., which is already intruding upon the present; the future is already speaking in the present and indeed writing the present. On the one hand, there are many possible futures, which is why we must remain open to its unforeseeability: anything at all may come about. On the other 
hand, the future has already been decided (indeed this is what is most agonizing about the decision), hence rendering impossible a situation in which a subject freely decides between various paths: the present is passive with regards to the future insofar as the future is already working it over, already speaking within it. The future - and this is where Derrida and Silesius truly come together - is that aspect of the present by which the latter lessens itself, incessantly reduces itself; the future is that which impoverishes the present, hollowing it out, making it less than what it is, insofar as it takes the fullness or the autonomy of the present - one of the key aspects of which is the present's ability to determine what it will become - and hollows it out by turning it into what it must invariably be, pointing it in a single, irrevocable direction. The future is the present's interruption or impoverishment of itself, that aspect of itself which is not yet, not in the sense of something that is not yet here, but rather in the sense of that which is just now coming into being: the future is at once the present's constitution and its undoing, or, better, its simultaneous self-proclamation and unsaying.

This future-as-impoverishment that comes about in the dialogue between Derrida and Silesius is what Hägglund's conceptual apparatus keeps him from understanding, for the simple reason that this future does not work on the level of the concept, but is rather that which at each moment subtracts itself from the latter: far from gathering seemingly disparate elements into a whole, as per the work of the concept, this future works by incompleting, undoing, unsaying. This is why one can't access it via the concept of desire on which Hägglund relies so heavily - is it any surprise that Derrida, whenever he deals with desire in Sauf le nom, treats it with such suspicion? There is of course a kind of desire at work in Derrida's text, a 'desire of the desert', as he suggests toward the end of the book. ${ }^{26}$ But one wonders whether the proper term for this ruined, unsaid desire wouldn't be desire at all, but rather faith, a faith that neither waits for nor seeks to appropriate that which is to come, but rather abandons itself to that which is already taking place. A faith, therefore, inseparable from works, and this is the sense - a quasi-mystical sense - in which it is revolutionary, in that the one who is traversed by it refuses to see any division between faith and world, any separation between the present and that which, for him or her, is already coming into being. ${ }^{27} \mathrm{~A}$ faith that unsays all of these 
divisions, incessantly; a faith of the not yet that is at the same time resolutely here and now. The faith of revolution.

\section{Notes}

1 Jacques Derrida, Sauf le nom, translated by John P. Leavey, Jr., in On the Name (Stanford, Stanford University Press, 1995), 69; Saufle nom (Paris, Galilée, 1993), 81 , translation modified. Page references to this text throughout the essay will refer first to the translation and then to the original, separated by a slash $(69 / 81)$.

2 See pages 35/16 and 36/18. Leibniz, in a passage cited by Heidegger, notes that in Silesius 'there are some places (...) inclining almost to Godlessness' (quoted in Derrida, Saufle nom, 36/16).

3 'Two interlocutors converse on a summer day' (xv/2, translation modified), as Derrida notes in the book's Prière d'insérer. It is tempting to identify the interlocutors, viewing the text as a conversation between Derrida and an alter ego, for example, or between deconstruction and negative theology. Neither of these claims truly fits - each 'speaker' is too complex to be reduced to a single identity - but it is not inaccurate to say that the book gives form to these and other conversations.

${ }^{4}$ In his essay 'How to Avoid Speaking: Denials', translated by Ken Frieden, in Derrida and Negative Theology, edited by Harold Coward and Toby Foshay (Albany, State University of New York Press, 1992), 73-142, Derrida notes with irony that 'very early I was accused of — rather than congratulated for - resifting the procedures of negative theology' (74).

5 Martin Hägglund, Radical Atheism: Derrida and the Time of Life (Stanford, Stanford University Press, 2008), 4.

6 Derrida, 'Différance', in Margins of Philosophy, translated by Alan Bass (Chicago, University of Chicago Press, 1982), 6.

7 Hägglund does add a footnote to this passage, directing the reader to the specific pages in Saufle nom and 'How to Avoid Speaking' in which Derrida 'repeats' his argument. This is at best misleading. In the pages indicated in Sauf le nom, for example, Derrida does speak of Silesius's positing of an entity that is 'beyond the name' (68/80, Derrida's emphasis). However, he does so only to suggest that this is one of the many tendencies we find in Silesius and indeed in negative theology as a whole: on the very next page, after noting that negative theology seeks to 'say and rejoin what is proper to God' (69/82, Derrida's emphasis), he notes that Silesius's use of the term 'proper' forces us to radically rethink our assumptions about this term. 
${ }^{8}$ One thinks here of Borges's story 'The Immortal', in which a group of people, having gained immortality, loses the desire to do anything, and indeed Hägglund comments on this story, if briefly, in his 'The Challenge of Radical Atheism: A Response', CR: The New Centennial Review 9:1 (2009), 227-252; see p. 250.

9 Ernesto Laclau makes a similar argument, upon which I draw here, in his essay 'Is Radical Atheism a Good Name for Deconstruction?', Diacritics 38:1-2 (2008), 180-189; see especially p. 180.

${ }^{10}$ Given that this claim - that deconstruction and religion are incompatible - is arguably the main claim of Hägglund's book, it is strange that he does not once mention Nancy's La Déclosion. Déconstruction du christianisme, I (Paris, Galilée, 2005), which appeared three years before Radical Atheism. The omission is striking not only because Nancy's book is arguably (I would certainly argue) the most important text on religion from within deconstruction at least since Derrida's Foi et savoir (Paris, Seuil, 2000 [1996]), but because many of Nancy's claims explicitly undermine those of Hägglund, for example when he writes that 'le christianisme est par lui-même, en lui-même, une déconstruction et une auto-déconstruction' (55); or when, in the essay 'Athéisme et monothéisme' — which begins with an epigraph from Schelling, 'Monotheism is an atheism' - he calls attention to the risk of overlooking or misunderstanding the complex interplay between the seemingly opposed terms 'theism' and 'atheism' (29-31).

11 By far the strangest of example of Hägglund's oppositions occurs in the introduction, when he says of his approach that it is 'analytical rather than exegetical' (11), as though such a distinction could ever make sense within deconstruction - as though, in deconstruction, exegesis were not always already analysis, and vice versa.

${ }^{12}$ In the introduction, for example, when Hägglund is describing the work that will follow, he speaks of chapters in which he 'develops a deconstructive logic of identity', 'develops the deconstructive notion of the synthesis of time' (10), etc.

13 See also Hägglund's comments about nothingness in Meister Eckhart and PseudoDionysius on pp. 117-119. I should note that Hägglund does not discuss Angelus Silesius in Radical Atheism. He does, however, speak time and again of negative theology as a whole, and makes several references to Saufle nom; these are two of the reasons for which I seek to put him in conversation with Silesius.

${ }_{14}$ Angelus Silesius, Cherubinischer Wandersmann (Stuttgart, Reclam, 1984), I: 24. All translations from this text are my own, except for the verses which are quoted in Derrida. I would like to thank Sarah Clift for her comments on these translations.

15 Quoted in Derrida, Saufle nom, 43/31. 
16 Sells, Mystical Languages of Unsaying (Chicago and London, The University of Chicago Press, 1994), 2.

17 Sells seems to have this very understanding, or something close to it, in mind when he writes of what he calls 'apophatic theory': 'some of what has been called apophasis is apophatic theory as opposed to apophatic discourse. Apophatic theory affirms the ultimate ineffability of the transcendent; but as opposed to apophatic discourse, it affirms ineffability without turning back upon the naming used in its own affirmation of ineffability' (3). Without kataphasis, in other words, there is no apophasis, since the latter 'is a relative term'; without kataphasis, it is merely 'asserted', not 'performed' (3). Tellingly for our purposes, Sells seems to have deconstruction in mind in this criticism of 'apophatic theory', and its shortcomings with regard to apophatic discourse: see pp. 224-225, notes 27 and 28.

18 I borrow this term from Lacoue-Labarthe and Nancy, who employ it to think the work of fragmentation in early German Romanticism. In my view, the term also applies, if in a different way, to the form of the Cherubinic Wanderer. The term 'fragment' is problematic here, insofar as each of Silesius's verses comprises a whole in and of itself; the fragment, on the other hand, only makes sense in its relationship with other fragments. Yet is this not precisely the way Silesius's book works doesn't the approach to the divine that he attempts lie not in any single verse, but rather in their totality? But what exactly is the nature of this totality? Usually when we use this word, we refer to different parts that come together to form a whole, and this is certainly part of what is taking place here. Yet the weakness of this totality lies in the fact that each specific verse seems, rather than adding something to the whole, to take something away from it, and this is precisely the work of the fragment as Lacoue-Labarthe and Nancy theorise it: every fragment incompletes the whole that it simultaneously works to create. See Philippe Lacoue-Labarthe and Jean-Luc Nancy, The Literary Absolute, translated by Philip Barnard and Cheryl Lester (Albany, State University of New York Press, 1988), especially the chapter 'The Fragment: The Fragmentary Exigency', in which they cite negative theology as the 'model' for the work of absence in the fragmentary writing of the Jena romantics (47).

19 Angelus Silesius, L'errant chérubinique, translated by Roger Munier (Paris, Arfuyen, 1993), 27.

20 A note in the Reclam edition of the Cherubinischer Wandersmann informs us that the original title of this couplet was 'The poorest' ('Der aermste'). See p. 304.

21 I am of course speaking of Odradek, whose 'laughter (...) has no lungs behind it'. See Kafka, 'The Cares of a Family Man', in The Complete Short Stories (London, Minverva, 1992), 428. 
22 Blanchot dedicated an essay to his work, entitled 'La Mystique d'Angelus Silesius', in Chroniques Littéraires du Journal des Débats, avril 1941-août 1944 (Paris, Gallimard, 2007), 466-473; Barthes comments on the Cherubinic Wanderer on several occasions in his course The Neutral, translated by Rosalind E. Krauss and Denis Hollier (New York, Columbia University Press, 2005), including it in the 'list of the texts whose reading, in various ways, has punctuated the preparation of this course' (1).

${ }^{23}$ As Blanchot says of the disaster in The Writing of the Disaster, translated by Ann Smock (Lincoln, University of Nebraska Press, 1995), 1.

${ }^{24}$ See Derrida's comments on this in Saufle nom, 100-102.

25 There is a major error in translation here: John P. Leavey, Jr. omits the word 'determinable' - all the stranger since Derrida emphasises it - thus completely changing Derrida's meaning.

26 'In listening to you,' one of Derrida's interlocutors states, 'one has more and more the feeling that desert is the other name, if not the proper place, of desire' (80/103).

27 While I cannot go into this in greater detail here, I want to make reference to three contemporary thinkers who have inspired the understanding of faith that I have sought to develop in this paper. The first is Žižek, who suggests that for a politics to consider itself revolutionary, it must have immediacy as its only horizon. In his 'Robespierre, or, the "Divine Violence" of Terror', for instance the introduction to the volume of Robespierre's writings that he edited, entitled Virtue and Terror (London and New York, Verso, 2007) - he contrasts 'the gradualism of compassionate liberals and the unique figure of John Brown' (xix), whom Žižek calls 'the key political figure in the history of the US' (xx): refusing the idea that blacks were 'not ready' for full equality, Brown advocated as the only possible way to deal with the problem of race an immediate equality between blacks and whites, and hence an absolute correspondence between the beyond and the here and now.

The second thinker is Ernesto Laclau, who, in his essay 'On the Names of God', in Political Theologies: Public Religions in a Post-Secular World, edited by Hent de Vries and Lawrence E. Sullivan (New York, Fordham University Press, 2006), 137-147, compares mystical detachment with 'the formation of the revolutionary will of a subordinated class' (141): on the one hand, he writes, this revolutionary will 'transcends all particular engagements and, in that sense, requires that the class be detached from them; on the other hand, without serious engagements in particular events there is no constitution of the revolutionary will' (141-2). As with the mystic, the revolutionary, in this formulation, engages with the world not to transcend it, but to see in it its own beyond, its own surpassing of itself. 
The final thinker is Nancy, who, in a chapter of his La Déclosion entitled 'Le judéo-chrétien (De la foi)', draws a link between two 'Jacques' — Derrida and the Biblical James - in order to put forth a thinking of faith in which 'les oeuvres (...) ne s'opposent pas à la foi: elles sont au contraire la foi elle-même' (76), and he explains this in terms that are of great interest to us here: 'la foi est le désoeuvrement qui a lieu dans et comme l'oeuvre' (77).

I will explore the links between faith and revolution in all three of these thinkers in a later work. 